\title{
Discard mortality played a major role in the loss of 10 billion juvenile scallops in the Mid-Atlantic Bight: Reply to Hart \& Shank (2011)
}

\author{
Kevin D. E. Stokesbury*, Jonathan D. Carey, Bradley P. Harris, Catherine E. O'Keefe \\ Department of Fisheries Oceanography, School for Marine Science and Technology, University of Massachusetts Dartmouth, \\ 200 Mill Road, Suite 325, Fairhaven, Massachusetts 02719, USA
}

\begin{abstract}
An exceptionally large year class $\left(1.31 \times 10^{10}\right.$ sea scallops $)$ was observed in 2003 in the Mid-Atlantic Bight. Over half of these scallops vanished by 2004. At this time the majority of fishing effort was focused in the Mid-Atlantic due to large closures on Georges Bank. We concluded that this mass mortality was likely the result of incidental fishing mortality. During harvest, scallops were exposed to lethal surface water and air temperatures. Fishermen reported large bycatches of small scallops which were discarded in the 2003-2004 fishing year. Hart \& Shank (2011; MEPS 443:293-297) argue that this hypothesis was not likely, as the mortality patterns observed were not consistent with those expected from high discard mortality, and suggested the alternative hypothesis that the mortality was caused by crab predation. After examining estimated retention rates of juvenile scallops collected in scallop dredges with $89 \mathrm{~mm}$ rings, prey size preference of crabs, and the limited observer data (5\% of 2003 fishing trips), we maintain that discard mortality, due to exposure to lethal water and air temperatures, played a major role in the decrease of juvenile scallop abundance in the Mid-Atlantic Bight.
\end{abstract}

KEY WORDS: Sea scallop · Placopecten magellanicus · Incidental fishing mortality $\cdot$ Crab predation

\section{Introduction}

Between 2003 and 2004, 10.4 billion sea scallops Placopecten magellanicus of 30 to $80 \mathrm{~mm}$ shell height disappeared in the Mid-Atlantic. We hypothesized that this disappearance was caused by incidental fishing mortality, specifically discard mortality where small scallops were captured, exposed to lethal surface water and air temperatures, and then discarded (Stokesbury et al. 2011). Hart \& Shank (2011) argue that this was not likely, as the mortality patterns observed were not consistent with those expected from high mortality due to discarding. They suggest that observer data supports their conclusion and that crab predation is more likely the cause of the mortality.

\section{Scallop retention in dredges}

From March 2003 to February 2004, 81 \% (23 533 t) of the total US scallop landings were harvested from the Mid-Atlantic using a New Bedford style dredge with an $89 \mathrm{~mm}$ (3.5 inch) ring. Hart \& Shank (2011) state that scallops larger than the dredge ring size are retained while a substantial proportion of small scallops escape through the dredge rings, citing Yochum \& DuPaul (2008). However, Yochum \& DuPaul (2008) examined catch selectivity of a 102 $\mathrm{mm}$ ring compared to the National Marine Fisheries Service (NMFS) lined dredge and did not examine an $89 \mathrm{~mm}$ ring dredge. Brust et al. (2001) estimated that a dredge with $89 \mathrm{~mm}$ rings has $57 \%$ retention for 
scallops 50 to $55 \mathrm{~mm}$ and 90 to $100 \%$ retention for scallops 100 to $105 \mathrm{~mm}$ shell height. Further, this was under normal fishing conditions with relatively low densities. In cases of extremely high densities, there is a higher likelihood that the rings and inter-ring spaces will become clogged by scallops or debris, resulting in increased retention of smaller scallops (Yochum \& DuPaul 2008). To reduce such retention, a $102 \mathrm{~mm}$ ring was implemented in 2004 (NEFMC 2003).

\section{Limited observer data}

Reports from scallop fishermen about large quantities of small scallops on deck (Figs. 1 \& 2) differ from the observer data on juvenile scallop bycatch that is cited in Hart \& Shank (2011). During the 2003 fishing year, there were 310 full-time equivalent vessels in the limited-access scallop fishery that spent a total of $31864 \mathrm{~d}$ at sea (NEFMC 2010a). A typical trip lasted $12 \mathrm{~d}$, resulting in approximately 2655 trips, of which roughly $80 \%$ were conducted in the Mid-Atlantic. Of these trips only 108 had observers on board from March 2003 to February 2004 (NEFSC 2010, Table 1B in their Appendix B2). Thus, there was only $5 \%$ observer coverage in the Mid-Atlantic throughout the entire fishing year, while the critical discard mortality would have occurred in July, August and September when water and air temperatures exceeded the scallops' lethal limit.

\section{Averaging confounds exceptional year class numbers}

To estimate incidental fishing mortality, Hart \& Shank (2011) examined the mean size frequency patterns of the population. They averaged the trend of the numbers of scallops per shell height bin over a number of years to reduce artifacts due to individual year classes. However, the point of our study is that the cohort of scallops observed in 2003 was exceptional; it was the result of a recruitment event that might occur once every 10 or more years. Averaging the year classes from 2003 to 2010 confounds the data and combines the high observed mortality of juvenile scallops during 2003-2004 with the increased fishing mortality resulting from large harvests after the Hudson Canyon, Elephant Trunk and Delmarva closed areas were opened to rotational fishing (NEFMC 2005, 2007, 2010b).

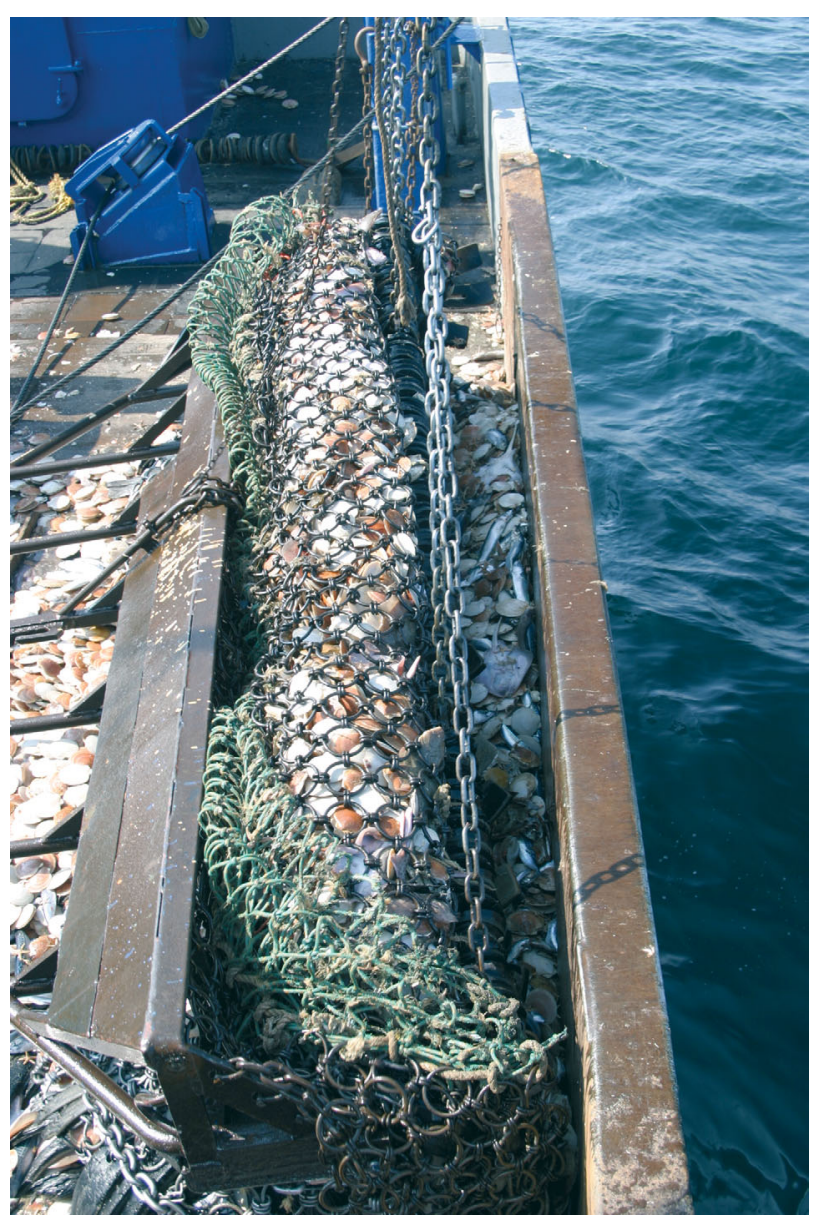

Fig. 1. New Bedford offshore dredge containing scallops Placopecten magellanicus captured in the Mid-Atlantic in 2003. New England fishing vessels (25 to $30 \mathrm{~m}$ ) typically deployed 2 dredges, each weighing about $1870 \mathrm{~kg}$ with a width of $4.5 \mathrm{~m}$, a series of vertical and horizontal sweep chains preventing large rocks from entering the bag, a $20.3 \mathrm{~mm}$ diamond mesh twine top for fish escapement, a $4.5 \times 0.8 \mathrm{~m}$ bag knit of $89 \mathrm{~mm}$ steel rings and rubber chaffing gear. (Photo by A. Cass)

\section{Crab predation}

Hart \& Shank (2011) point out that high densities of small scallops may attract predators as demonstrated in the seeding experiments of Hatcher et al. (1996) and Barbeau et al. $(1996,1998)$. Crab predation can lead to considerable reduction in the number of small scallops (Stokesbury \& Himmelman 1995). However, the densities of crabs observed in the areas of high scallop aggregation (Fig. 1 in Stokesbury et al. 2011), averaging $\left( \pm\right.$ SE) $0.05 \pm 0.016 \mathrm{crabs} \mathrm{m}^{-2}$ in 2003 and $0.03 \pm 0.013 \mathrm{crabs} \mathrm{m}^{-2}$ in 2004, were lower than the overall densities for the Mid-Atlantic (843 stations with $0.78 \pm 0.157$ crabs m$^{-2}$ in 2003 and $0.29 \pm 0.032$ 


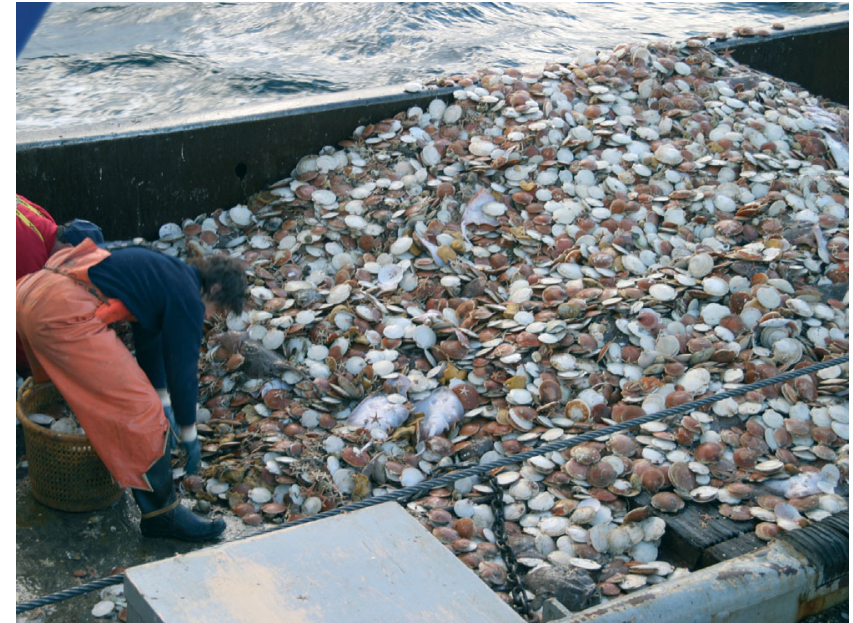

Fig. 2. Dredge contents of a tow from the Mid-Atlantic in 2003, including scallops Placopecten magellanicus of varying sizes and species that may clog the dredge. Scallops are processed at sea; the catch is sorted, and rocks, small scallops, and unwanted fish are removed by hand. Usually only 2 to 3 crew members are on deck to process the catch, which can take several hours. In the summer months these scallops are exposed to surface water and air temperatures above their lethal limit. (Photo by A. Cass)

crabs $\mathrm{m}^{-2}$ in 2004). This suggests that crabs were not aggregating in the areas with high scallop recruitment. This may be due to the size-refuge bivalves experience from decapod predation (Juanes 1992). Crabs actively select smaller scallops, preferring 20 to $30 \mathrm{~mm}$ and 30 to $50 \mathrm{~mm}$ shell height when offered 20 to $70 \mathrm{~mm}$ and 30 to $110 \mathrm{~mm}$ shell height scallops, respectively (Elner \& Jamieson 1979, Jamieson et al. 1982). The scallops observed in 2003 were larger than the preferred size range of crabs. The consumption rates cited by Hart \& Shank (2011) were for scallops with mean shell heights of $34.1 \pm 4.2 \mathrm{~mm}$ and $36.5 \pm$ $4.9 \mathrm{~mm}$ (Wong \& Barbeau 2005) and 25 to $35 \mathrm{~mm}$ (Nadeau et al. 2009), which are smaller than the mean shell height of scallops we observed in 2003. Hart (2006) concluded that crabs Cancer spp. had no significant effect on scallop recruitment in the MidAtlantic from 2000 to 2002, when scallops from the exceptional 2001 year class would have been at optimal prey size. We maintain that crab predation was a less likely cause of the high mortality of small scallops between 2003 and 2004 than discard mortality.

\section{Conclusions}

As noted by Hart \& Shank (2011), the cause of the high mortality of juvenile scallops during 2003-2004 may never be known for certain. It is likely that both natural and fishing-related mortality played a role in the loss of 10.4 billion scallops. However, accepting one or the other of these hypotheses as the primary cause has profound implications for fisheries management. If the crab predation hypothesis is correct, then it was a natural occurrence and the timeframe of 13 mo required by NMFS to implement a protective closed area (the Elephant Trunk area) had no effect on the health of the stock. However, we maintain that discard mortality played a major role in the decrease of juvenile scallop abundance in the Mid-Atlantic between 2003 and 2004, and to avoid similar losses in the future requires real-time, spatially specific information and rapid responses by management.

Acknowledgements. We thank A. Cass for providing photographs from his fishing trips in the Mid-Atlantic in 2003. Financial aid was provided by NOAA award NA10NMF4720288. The views expressed herein are those of the authors and do not necessarily reflect the views of NOAA or any other agencies.

\section{LITERATURE CITED}

Barbeau MA, Hatcher BG, Scheibling RE, Hennigar AW, Taylor LH, Risk AC (1996) Dynamics of juvenile sea scallop (Placopecten magellanicus) and their predators in bottom seeding trials in Lunenburg Bay, Nova Scotia. Can J Fish Aquat Sci 53:2494-2512

Barbeau MA, Scheibling RE, Hatcher BG (1998) Behavioural responses of predatory crabs and sea stars to varying density of juvenile sea scallops. Aquaculture 169:87-98

Brust J, DuPaul W, Kirkley J (2001) The effects of a regulatory gear restriction on the recruiting year class in the sea scallop, Placopecten magellanicus, fishery. J Shellfish Res 20:1035-1041

> Elner RW, Jamieson GS (1979) Predation of sea scallops, Placopecten magellanicus, by the rock crab, Cancer irroratus, and the American lobster Homarus americanus. J Fish Res Bd Can 36:537-543

Hart DR (2006) Effects of sea stars and crabs on sea scallop Placopecten magellanicus recruitment in the MidAtlantic Bight (USA). Mar Ecol Prog Ser 306:209-221

Hart DR, Shank BV (2011) Mortality of sea scallops Placopecten magellanicus in the Mid-Atlantic Bight: Comment on Stokesbury et al. (2011). Mar Ecol Prog Ser 443: 293-297

Hatcher BG, Scheibling RE, Barbeau MA, Hennigar AW, Taylor LH, Windust AJ (1996) Dispersion and mortality of a population of sea scallop (Placopecten magellanicus) seeded in a tidal channel. Can J Fish Aquat Sci 53:38-54

Jamieson GS, Stone H, Etter M (1982) Predation of sea scallops (Placopecten magellanicus) by lobsters (Homarus americanus) and rock crabs (Cancer irroratus) in underwater cage enclosures. Can J Fish Aquat Sci 39:499-505

Juanes F (1992) Why do decapod crustaceans prefer smallsized molluscan prey? Mar Ecol Prog Ser 87:239-249

Nadeau M, Barbeau MA, Brêthes JC (2009) Behavioural mechanisms of sea stars (Asterias vulgaris Verrill and 
Leptasterias Polaris Müller) and crabs (Cancer irroratus Say and Hyas araneus Linnaeus) preying on juvenile sea scallops (Placopecten magellanicus (Gmelin)), and procedural effects of scallop tethering. J Exp Mar Biol Ecol 374:134-143

NEFMC (New England Fisheries Management Council) (2003) Final amendment 10 to the Atlantic sea scallop fishery management plan with a supplemental environmental impact statement, regulatory impact review and regulatory flexibility analysis. NEFMC, Newburyport, MA

NEFMC (2005) Framework Adjustment 18 to the Atlantic sea scallop fishery management plan including an environmental assessment, regulatory impact review, regulatory flexibility analysis and stock assessment and fishery evaluation report. NEFMC, Newburyport, MA

NEFMC (2007) Framework Adjustment 19 to the Atlantic sea scallop fishery management plan including an environmental assessment, an initial regulatory flexibility analysis and stock assessment and fishery evaluation report. NEFMC, Newburyport, MA

NEFMC (2010a) Amendment 15 to the scallop fishery management plan including a final environmental impact statement. NEFMC, Newburyport, MA

NEFMC (2010b) Framework Adjustment 21 to the Atlantic sea scallop fishery management plan including an envi-

Editorial responsibility: Christine Paetzold, Oldendorf/Luhe, Germany ronmental assessment, an initial regulatory flexibility analysis and stock assessment and fishery evaluation report. NEFMC, Newburyport, MA

NEFSC (Northeast Fisheries Science Center) (2010) Atlantic sea scallop stock assessment for 2010. In: 50th northeast regional stock assessment workshop (50th SAW) assessment report. Ref Doc 10-17, US Dept Commerce, Northeast Fisheries Science Center, Woods Hole, MA, p 393-708

Stokesbury KDE, Himmelman JH (1995) Biological and physical variables associated with aggregations of the giant scallop Placopecten magellanicus. Can J Fish Aquat Sci 52:743-753

> Stokesbury KDE, Carey JD, Harris BP, O'Keefe CE (2011) Incidental fishing mortality may be responsible for the death of ten billion juvenile sea scallops in the midAtlantic. Mar Ecol Prog Ser 425:167-173

> Wong MC, Barbeau MA (2005) Prey selection and the functional response of sea stars (Asterias vulgaris Verrill) and rock crabs (Cancer irroratus Say) preying on juvenile sea scallops (Placopecten magellanicus (Gmelin)), and blue mussels (Mytilus edulis Linnaeus). J Exp Mar Biol Ecol 327:1-21

> Yochum N, DuPaul WD (2008) Size-selectivity of the northwest Atlantic sea scallop (Placopecten magellanicus) dredge. J Shellfish Res 27:265-271

Submitted: November 16, 2011; Accepted: November 21, 2011 Proofs received from author(s): November 25, 2011 